\title{
Enhancing the Sustainability of Temperate Pasture Systems through More Diverse Swards
}

\author{
David M. Jaramillo ${ }^{1, * \mathbb{C}}$, Helen Sheridan ${ }^{2}$, Kathy Soder $^{3}$ and Jose C. B. Dubeux, Jr. ${ }^{4}$ \\ 1 U.S. Dairy Forage Research Center, United States Department of Agriculture-Agricultural Research Service, \\ Marshfield, WI 54449, USA \\ 2 School of Agriculture and Food Science, University College Dublin, Belfield, 4 Dublin, Ireland; \\ helen.sheridan@ucd.ie \\ 3 Pasture Systems and Watershed Management Research Unit, United States Department of \\ Agriculture-Agricultural Research Service, University Park, PA 16802, USA; kathy.soder@usda.gov \\ 4 North Florida Research and Education Center, University of Florida, Marianna, FL 32446, USA; \\ dubeux@ufl.edu \\ * Correspondence: david.jaramillo@usda.gov
}

Citation: Jaramillo, D.M.; Sheridan, H.; Soder, K.; Dubeux, J.C.B., Jr. Enhancing the Sustainability of Temperate Pasture Systems through More Diverse Swards. Agronomy 2021, 11, 1912. https://doi.org/10.3390/ agronomy11101912

Academic Editors: Juan J. Villalba and Jennifer MacAdam

Received: 31 August 2021

Accepted: 22 September 2021

Published: 24 September 2021

Publisher's Note: MDPI stays neutral with regard to jurisdictional claims in published maps and institutional affiliations.

Copyright: (c) 2021 by the authors. Licensee MDPI, Basel, Switzerland. This article is an open access article distributed under the terms and conditions of the Creative Commons Attribution (CC BY) license (https:/ / creativecommons.org/licenses/by/ $4.0 /)$.

\begin{abstract}
Temperate grasslands can be highly productive. However, those that are productive are generally heavily dependent on high inputs of nitrogen $(\mathrm{N})$ fertilizer. Including legumes such as white clover (Trifolium repens L.) in the sward can reduce reliance on $\mathrm{N}$ fertilizer. Recent investigations have evaluated the potential of multispecies swards, which are defined as agronomically improved grasslands that include multiple plant functional groups, e.g., grasses, legumes, and forage forbs. Several of the benefits and challenges of multispecies swards are summarized in this review. To date, the most prominent forb species included in multispecies swards are chicory (Cichorum intybus L.) and ribgrass/ribwort plantain (Plantago lanceolata L.). Multispecies swards grown under reduced N fertilizer input conditions can produce as much biomass as monocultures receiving large quantities of $\mathrm{N}$ fertilizer. The nutritive value of multispecies swards may potentially be greater than grass-only swards, especially since forbs may contribute additional micro and macro minerals to livestock diet. While challenges associated with multispecies swards may include weed management and facilitating persistence of the forb species in particular, the overall evidence suggests that wellmanaged multispecies swards can enhance the productivity as well as environmental sustainability of grazing systems.
\end{abstract}

Keywords: biodiversity; forage; forb; grazing; legume; multispecies; sward

\section{Introduction and Background}

Grasslands make up more than $40 \%$ of Earth's terrestrial surface, of which grazing lands occupy the largest single land-use type, encompassing more than 40 million $\mathrm{km}^{2}$ [1-3]. Livestock production is an important economic activity worldwide, accounting for $50 \%$ of the global agricultural gross domestic product [4,5]. Forages play an especially important role in livestock production systems since forage grasses are the most commonly consumed livestock feed in the world [6]. Grazed ecosystems can range from intensively managed monocultures with high stocking rates, high inputs, e.g., fossil fuels, fertilizer, and herbicides, and which may be regularly resown to extensively managed, permanent grasslands, rangelands, and semi-arid savannas that function as low-input ecosystems [6]. To generalize, extensively managed systems oftentimes result in agriculturally unproductive grasslands, largely due to limited soil nitrogen (N) [7], while the high levels of nutrient inputs, in the form of synthetic fertilizers or animal excreta, associated with intensively managed grasslands, may result in negative environmental impacts, including greenhouse gas emissions, water pollution, and loss of biodiversity [5,8]. While these two situations represent extremes in nutrient availability, there are many variations in management that 
result in a continuum that will have tradeoffs in nutrient management, environmental impact, and the overall productivity of a system.

The more intensive end of the agricultural spectrum has really developed since the mid-20th century [9]. Technological advancements led to increased production efficiencies, transforming farming systems into specialized, simplified, and more energy-intensive production systems [9]. However, these advances in production have often been at the expense of ecosystem biodiversity [10]. This has resulted in decreased ecosystem resilience, which is the manner in which an ecosystem can withstand disturbance without crossing a threshold to a different way of functioning [9].

However, recent investigations have suggested that including plants from contrasting functional groups (e.g., grasses, legumes, and forbs) may be beneficial in terms of herbage production and the delivery of ecosystem services [11-13]. Within this context, a forb is henceforth referred to as a non-legume, dicotyledonous, broad-leaved plant that is agronomically beneficial [14]. Such swards are denoted as multispecies swards and are characterized by functionally different, but compatible species. Since each individual species occupies a particular niche, they are not in direct competition with each other and can benefit from growing in mixtures [15]. The objectives of this paper are to review pertinent literature relevant to the agronomic and livestock production aspects of multispecies pasture systems in temperate regions, evaluate the potential benefits and drawbacks associated with their use, discuss potential challenges of implementation of these systems in temperate regions, and identify future research needs to improve economic and environmental sustainability of grazing-based livestock systems.

\section{Characteristics of Temperate Grazing Systems}

Livestock grazing systems in temperate regions have become increasingly specialized over recent decades largely as a result of ease of applying $\mathrm{N}$ fertilizers and use of herbicides, which has resulted in the increasing emphasis on the use of perennial cool-season $\left(\mathrm{C}_{3}\right)$ grass monocultures [16]. The dominant species utilized in these monocultures may differ across pasture, farm, regional, and continental scales [17,18]. Perennial ryegrass (Lolium perenne L.), Italian ryegrass (L. multiflorum L.), and hybrid ryegrass (Lolium $\times$ boucheanum Kunth) are among the predominant forage grasses in north-western Europe, New Zealand, and the temperate regions of Australia, Japan, South Africa, and South America [19]. However, perennial ryegrass is the most important of these species, and much of the grassland research in temperate regions in recent decades has focused on its use. There are many good reasons for this, including its ability to sustain high productivity of good quality forage, adaptability to a range of growing conditions [20], ability to recover quickly following defoliation $[10,21]$, and reliable germination. However, perennial ryegrass requires high levels of applied $\mathrm{N}$ to maintain productivity, and it does not persist across all temperate regions [22,23].

Tall fescue [Lolium aundinaceum (Schreb.) S.J. Darbyshire] represents another widely utilized forage grass commonly found in temperate regions of the U.S.A. and southern Europe [19]. It is estimated that tall fescue covers 14.3 million hectares worldwide, which is comparable to that covered by perennial ryegrass [19]. Perhaps the most favoring characteristics of tall fescue include its capacity to tolerate heat, drought, and intensive grazing, as well as its persistence in poorly drained soils [19]. Many of these positive attributes result from the presence of Epichloë coeno-phiala (previously known as Neotyphodium coenophialum), which is an endophytic fungus that produces secondary metabolites and increases the plant fitness factors [24,25]. This endophyte, however, produces toxic ergot alkaloids and consumption of endophyte-infected forages causes fescue toxicosis, leading to reduced weight gains and poor reproductive performance [24]. Non-toxic novel endophyte-containing and non-endophyte-containing tall fescue varieties have been developed within recent years and are available in the seed market [25]. Persistence of these novel endophyte-infected tall fescue varieties can be similar to toxic endophyte-infected varieties [25]. 
Orchardgrass (or cocksfoot) (Dactylis glomerata L.) represents another important forage grass in temperate regions. Orchardgrass has mainly been utilized in North America, ranging from southern New York state (U.S.A.) to Virginia and from the Atlantic seaboard to eastern Nebraska [26] and, also, throughout various parts of Europe. [19]. Orchardgrass exhibits heat and drought tolerance under Mediterranean climate conditions, but is not tolerant of poorly drained soil conditions and is only moderately winter hardy [27]. Compared to other cool-season grasses, orchardgrass is classified as intermediate in crude protein concentrations, high in fiber, and intermediate in lignin and digestibility [26]. Orchardgrass is also generally considered to provide excellent spring growth with high proportion of leaf and good summer and fall productivity [26]. Breeding and selection efforts have resulted in several varieties or orchardgrass that persist well under grazing management [28].

Several other forage grasses tend to be of much more localized importance [19]. Meadow fescue [Schedonorus pratensis (Huds.) P. Beauv.] has become an increasingly important forage species in north-central U.S.A. [29,30]. Several meadow fescue cultivars have also been developed, and indications are that these have superior digestibility when compared with either tall fescue or orchardgrass $[29,30]$. Other important grass species in temperate regions include, but are not limited to, smooth bromegrass (Bromus inermis Leyss), reed canary grass (Phlaris arundinacea L.), and timothy (Phleum pratense L.) [31].

\subsection{Grass-Legume Systems}

Binary-mixed pasture systems consisting of grasses and legumes in temperate regions have been widely shown to be both productive and persistent [32]. Early 20th-century pasture management research advocated the use of complex mixtures of grasses and legumes; however, adoption of these systems has been limited. This was due to several reasons, not least of which were: the ready availability of inorganic $\mathrm{N}$ fertilizers at relatively low cost, which in turn gave rise to a growing reliance on inorganic $\mathrm{N}$ fertilizers, and poor interspecies competition leading to inadequate establishment and persistence [33,34]. In recent decades, however, there has been increasing interest in incorporating forage legumes into grazing systems [35]. For instance, in the last 25 years, over 50\% of sown pastures in France have contained grasses and white clover, when in 1985, only about $10 \%$ of pastures contained such mixtures [32]. Similar trends have also been reported in New Zealand and temperate regions in the U.S.A., especially with regard to the inclusion of Trifolium spp. and alfalfa varieties [36-38]. Advances in plant breeding efforts to develop more productive cultivars and selection for grazing tolerance have played positive roles in providing options for farmers $[34,36,39]$. Pasture systems consisting of white clover and perennial ryegrass are representative of successful grass-legume mixtures, representing much of the temperate regions today, especially Europe and New Zealand [32].

Plant species diversity in sown pasture systems can have positive impacts on plant nutrient acquisition when grown under conditions of limited resources [40]. Increased plant species diversity generally results in improved utilization of the total niche space due to niche differentiation of species, positive interspecific interactions, and greater probability of containing highly productive species $[40,41]$. In pasture systems, the incorporation of forage legumes can reduce the need for applied fertilizer $\mathrm{N}$, while also producing greater or equal amounts of forage compared to heavily N-fertilized grass monocultures [42] Thus, the use of legumes in grazing-based livestock systems is considered an important component of sustainable and competitive grazing systems [12,43,44]. Sleugh et al. [42] showed that incorporating legumes into temperate grass pastures can improve the nutritive value (crude protein, digestibility) and seasonal distribution of herbage accumulation. Alfalfa-grass mixtures also showed greater herbage accumulation compared to N-fertilized grass monocultures, since the mixtures benefited from the deep tap-root system of alfalfa, which were capable of exploiting water resources from deeper into the soil layers [42]. There are also opportunities for increasing soil organic carbon concentrations through legume inclusion in perennial cool-season grass pastures [12]. Several mechanisms have been suggested and are mostly driven by the ability of legumes to fix $\mathrm{N}$, especially since 
$\mathrm{N}$ is a substrate for soil organic matter (OM) formation [12,45]. For further review of grass-legume literature, see Jensen et al. [45] and Peyraud et al. [32].

\subsection{Environmental Policy}

Growing concern regarding the environmental sustainability of livestock production systems has led to the implementation of policy to limit dependence on inputs such as $\mathrm{N}$ fertilizer. For example, the European Union's Nitrates Directive, Council Directive 91/676/EEC, limits the use of N-fertilizers in agriculture [46]. More recently, the European Green Deal has set out a strategy for the EU to become the first carbon neutral continent by 2050 [47]. Key to this achievement will be the implementation of the EU Farm to Fork Strategy, which commits to a reduction of at least $20 \%$ in the use of fertilizers by 2030 [48]. The U.S.A. has also set targets to achieve $50 \%$ reduction in greenhouse gas emissions, with special focus on reducing emissions from agricultural practices and enhancing $C$ sequestration from various ecosystems, including agricultural soils [49]. Furthermore, New Zealand has also implemented several policies establishing the minimal acceptable conditions for freshwater bodies across several contaminant categories, especially including nitrates and phosphorous [50,51]. These policies play a role in aiming to achieve the goals set forth by the Paris Climate Agreement, which attempts to minimize the impact of climate change and keeping temperature rise below $2{ }^{\circ} \mathrm{C}[52,53]$. Given the growing global human population and the growing desire for animal protein, there is an urgent need to learn how to produce more using fewer inputs and achieving sustainable intensification to also protect the environment.

\section{Multispecies Swards}

In most situations, multispecies swards are composed between three and twelve species, and each species is typically selected to bring an agronomic benefit to the sward, since they can exploit complementarity and interspecific interactions [54] (Table 1). The complementarity between grasses and legumes utilized in these swards are beneficial, since they can convert available resources to high quality forage, benefiting from biological $\mathrm{N}_{2}$ fixation [54]. Incorporating forage forbs is thought to occupy the niche of weed species and improve resource utilization in the sward [55]. Evidence shows the potential for a positive correlation in the improvement of aboveground herbage biomass production and the plant-species diversity of grassland systems [41]. This relationship, however, is highly dependent on the productivity of the species utilized [41].

Initial interest in forage forb inclusion into grazed pastures occurred in the early 20th century during the formation of the Welsh Plant Breeding Institute [56]. At that time, there were indications from plot studies that several mineral-rich forb species had potential to be beneficial for livestock through diet improvements [56]. Commonly utilized forbs in multispecies swards have historically included chicory (Cichorum intybus L.), ribgrass/ribwort plantain (Plantago lanceolata L.), yarrow (Achillea millefolium L.), burnet (Sanguisorba minor Scop.), sheep's parsley [Petroselinum crispum (Mill.) Fuss], cat's ear dandelion (Hypochoeris radicata L.), and caraway (Carum carvi L.) [56,57]. These perennial forb species are often considered pasture weeds, though cultivated varieties, selected for grazing tolerance and forage production, have now been developed for at least some of them [58]. Research and breeding efforts from New Zealand resulted in the release of "Grasslands Puna" and "Grasslands Lancelot", which were the first two commercial cultivars of chicory and plantain, respectively $[59,60]$. 
Table 1. Selected studies describing the use of multispecies swards in temperate regions.

\begin{tabular}{|c|c|c|c|}
\hline Location & Treatments and Approach & Outcome and Considerations & Reference \\
\hline Ireland & $\begin{array}{l}\text { Cutting vs. grazing } 5 \text { different sward types } \\
\text { consisting of grass, grass-legume, } 6 \text { or } \\
9 \text { multispecies swards. }\end{array}$ & $\begin{array}{l}\text { Multispecies swards had lesser herbage accumulation under } \\
\text { grazing vs. cutting. Herbage accumulation of grass } \\
\text { monocultures was not affected by defoliation method. } \\
\text { Legume and forb proportion were reduced under } \\
\text { cattle grazing. }\end{array}$ & [23] \\
\hline Ireland & $\begin{array}{l}\text { Sheep grazing } 4 \text { different sward types } \\
\text { consisting of grass, grass-legume, } 6 \text { or } \\
9 \text { multispecies swards. }\end{array}$ & $\begin{array}{l}\text { Multispecies pastures had similar herbage production as } \\
\text { N-fertilized grass. Reduced proportions of legume and forbs } \\
\text { over time. Challenge of sustaining forb proportion in the } \\
\text { sward. Lambs had greater average daily gains and body } \\
\text { condition score and reduced fecal egg counts, when grazing } \\
\text { multispecies swards compared to perennial } \\
\text { ryegrass monoculture. }\end{array}$ & {$[11,61]$} \\
\hline Ireland & $\begin{array}{l}\text { Ensilability of binary (grass-legume) and } \\
\text { multispecies swards utilized was compared to } \\
\text { grass monocultures utilizing laboratory silos. }\end{array}$ & $\begin{array}{l}\text { Binary grass-clover and multispecies swards had a greater } \\
\text { requirement for adequate field wilting or preservative } \\
\text { application, compared to perennial ryegrass monocultures. }\end{array}$ & [62] \\
\hline France & $\begin{array}{l}\text { Lactating dairy cows grazing simple to } \\
\text { complex multispecies pastures. }\end{array}$ & $\begin{array}{l}\text { Greater DM intake and milk production from } \\
\text { multispecies swards. }\end{array}$ & [63] \\
\hline New Zealand & $\begin{array}{l}\text { Lactating dairy cows grazing binary or } \\
\text { multispecies pastures. }\end{array}$ & $\begin{array}{l}\text { Legume proportion in sward affected milk production more } \\
\text { than number of species. Multispecies pastures reduced N } \\
\text { losses without compromising milk yield. }\end{array}$ & [64] \\
\hline New Zealand & $\begin{array}{l}\text { Authors assessed how the grazing behavior of } \\
\text { dairy cows was affected by dietary } \\
\text { proportions of chicory or plantain fed as } \\
\text { monocultures for part of the day. }\end{array}$ & $\begin{array}{l}\text { Rumination time was reduced by up to } 90 \text { min when chicory } \\
\text { and plantain composed } 60 \% \text { of the diet. Cows grazing } \\
\text { chicory and plantain exhibited greater mastication during } \\
\text { ingestion and reduced their rumination time and chewing. } \\
\text { Cows consumed } 20 \% \text { less chicory compared with plantain. }\end{array}$ & [65] \\
\hline USA & $\begin{array}{l}\text { Lactating dairy cows grazing binary } \\
\text { grass-legume, or } 3,6 \text {, or } \\
9 \text { multispecies swards. }\end{array}$ & $\begin{array}{l}\text { Intake was similar across treatments; no effect on milk } \\
\text { production. Greater conjugated linoleic acid in milk from } \\
\text { multispecies swards. Multispecies swards did not affect } \\
\text { cow performance. }\end{array}$ & [66] \\
\hline USA & $\begin{array}{l}\text { Authors evaluated three seeding methods of } \\
\text { re-establishing chicory in multispecies } \\
\text { pastures. Seeding methods included frost } \\
\text { seeding in winter, no-till seeding in early } \\
\text { spring, and broadcast seeding in late spring. }\end{array}$ & $\begin{array}{l}\text { The three seeding methods did not differ from each other, } \\
\text { and all resulted in the adequate re-establishment of chicory. } \\
\text { In all instances, however, persistence was poor after the first } \\
\text { year, with mortality rates of } 77-84 \% \text { by the fall of the seeding } \\
\text { year. Greater suppression of existing vegetation and greater } \\
\text { seeding rates are required for successful } \\
\text { reestablishing chicory. }\end{array}$ & {$[67]$} \\
\hline USA & $\begin{array}{l}\text { Forage production of grazed pastures } \\
\text { consisting of grass-legume mixture or } \\
\text { 9-species multispecies pastures }\end{array}$ & $\begin{array}{l}\text { Across } 9 \mathrm{y} \text {, multispecies pastures produced } 31 \% \text { more } \\
\text { herbage. Multispecies swards had greater soil C } \\
\text { accumulation than binary mixes. }\end{array}$ & {$[68]$} \\
\hline USA & $\begin{array}{l}\text { Grazed pastures consisting of four mixtures ( } 2, \\
3,6 \text {, and } 9 \text { species) of multispecies swards, all } \\
\text { containing chicory. }\end{array}$ & $\begin{array}{l}\text { Multispecies pastures containing chicory }(3,6 \text {, and } 9 \text { species } \\
\text { swards) had greater herbage accumulation rates than binary } \\
\text { grass-legume swards. }\end{array}$ & [69] \\
\hline
\end{tabular}

\subsection{Herbage Accumulation from Multispecies Swards}

Multispecies swards can produce similar, or greater, herbage DM accumulation at reduced levels of $\mathrm{N}$ fertilizer compared to grass monocultures [11]. Similar to the mechanisms in grass-legume mixtures, improvements in herbage accumulation are attributed to greater resource use efficiencies [18]. Nobilly et al. [70] showed an excess $1.62 \mathrm{Mg} \mathrm{DM}^{-1}$ over the year, from multispecies swards (consisting of perennial ryegrass, tall fescue, white clover, red clover, alfalfa, chicory, and plantain) compared to two-species (perennial ryegrass-white clover) mixes. The enhanced herbage accumulation was attributed to the contribution of the forbs in the botanical composition of the pastures.

In a two-year grazing study, Sanderson et al. [71] reported lesser herbage DM accumulation from a two-species (orchardgrass-white clover) mixture, compared with three species (orchardgrass, white clover, and chicory), six species (orchardgrass, tall fescue, perennial ryegrass, red clover, birdsfoot trefoil, and chicory), and nine species (the sixspecies mixture plus white clover, alfalfa, and Kentucky bluegrass) mixtures, during times of soil moisture deficits. Herbage accumulation was similar across all treatments during 
the second year [71]. However, in the third year of that study, most of the mixtures were reverting back to orchardgrass-white clover, with diversity between treatments decreasing [71]. Under simulated grazing, Skinner et al. [72] report greater herbage accumulation from multispecies swards consisting of chicory, orchardgrass, bluegrass, perennial ryegrass, and white clover, compared with simple mixes consisting of bluegrass and white clover, both in dry and normal soil moisture conditions. Similar to Nobilly et al. [70] and Sanderson et al. [71], Skinner et al. [72] attributed the increases in herbage accumulation to the chicory, which is likely capable of increasing soil moisture in shallow soil layers through hydraulic lifting of water from deeper in the soil profile. However, chicory tends to bolt in the summer in regions with high ambient temperatures. This may reduce its preference by the grazing animal, which might present other challenges in terms of management and sustaining pasture botanical composition [72].

Increasing the number of species within a sward does not always result in a positive response in terms of herbage accumulation $[39,73]$. Increasing species richness in a limitedresource system may only lead to a finer division of these resources rather than increasing herbage productivity [74]. It is suggested that transgressive overyielding can occur as a factor of functional diversity and the niche-use complementarity among species in a sward $[41,54,73]$. Functional traits including seasonal growth distribution, root-system architecture, herbage canopy structure, and biological $\mathrm{N}_{2}$ fixation are fundamental to having complete use of resources and, thus, improved production efficiencies [73]. In most instances, the main influence on herbage accumulation is environmental (e.g., site, fertility, and slope) rather than species diversity and is related to the presence of a given species rather than the number of species [39].

\subsection{Nutritive Value and Forage Quality}

Compared with perennial ryegrass, chicory and plantain have lesser fiber and crude protein and greater mineral concentrations [65] (Table 2). Vegetative chicory material tends to have greater OM digestibility than several temperate grasses, whereas the OM digestibility of plantain is similar to that of temperate grasses [65,75]. Grazing multispecies swards is generally hypothesized to have increased DMI; however, this has not been consistently observed. In a metanalysis comparing multispecies and grass or grass-legume swards, McCarthy et al. [76] reported no differences in overall DMI. Lesser NDF concentrations in multispecies swards, compared to grass or grass-legume swards, are generally attributed to having an effect on DMI [76]. Furthermore, McCarthy et al. [76] reported $1.20 \mathrm{~kg} \mathrm{~d}^{-1}$ increase in milk yield, per cow, in multispecies swards. The analyses also showed significant increases in milk component yield for cows grazing multispecies swards, with energy-corrected milk (ECM), fat, protein, and combined fat and protein all increasing [76]. These differences in milk component composition are likely attributed to the differences in nutrient concentrations of multispecies swards [76].

The inclusion of chicory and plantain in the diet of grazing cattle has also been shown to reduce rumination time and ruminative chews, compared with those grazing ryegrass [65]. Reduction in ruminative chews might suggest greater particle breakdown during ingestion, thus reducing the need for rumination and faster clearance of digesta from the rumen [65]. Clearance of digesta from the rumen clears room and stimulates feeding, thereby increasing overall intake $[65,77]$. However, these effects are highly dependent on the overall proportion of forage forbs (chicory or plantain) in the pasture and the quantity selected by the grazing animal. A greater selection for these species will likely affect their persistence and consequently decrease their presence in the pasture.

Anti-quality factors have also been reported from multispecies swards, mainly as a contribution from the forb component. Plant secondary metabolites can exert both anti-nutritional and nutritional effects upon the forage nutritive value [78]. Condensed tannins are among the most extensively studied plant secondary metabolites, which can affect animal nutrition through their ability to protect proteins from ruminal degradation [78]. Chicory is reported to have low concentrations (ranging between 0.5 and 
$2.5 \mathrm{~g} \mathrm{~kg}^{-1}$ ), while plantain is regarded to have medium concentrations (ranging between 4 and $14 \mathrm{~g} \mathrm{~kg}^{-1}$ ) $[75,78,79]$. However, concentrations below $17 \mathrm{~g} \mathrm{~kg}^{-1}$ are considered unlikely to protect against ruminal degradation [75].

Other prominent secondary metabolites in chicory are sesquiterpene lactones, which impart a bitter taste to the herbage and possibly deter animal grazing $[66,80]$. The total concentrations of these compounds are affected by both cultivar and season, where the sesquiterpene lactone concentration has been reported to be lesser in autumn than spring or summer [81]. Under grazing management, post-grazing residues have been found to contain high proportions of chicory, suggesting cattle avoidance, where they preferentially select grasses and legumes [66,71].

Plantain herbage can contain secondary metabolites that have antimicrobial properties and anti-oxidative activity [82]. The three main secondary plant metabolites in plantain include aucubin, catalpol, and acteoside [82-84]. Aucibin and catalpol have been shown to have anti-inflammatory properties in mice [85], and aucibin stimulates removal of uric acid from tissues to the blood, as well as the excretion of uric acid from the kidneys [84]. In vitro incubations showed that aucibin and acteoside reduce $\mathrm{NH}_{3}$ production via bactericidal and inhibitory effect on ruminal fermentation [86]. Acteoside is known for its antimicrobial properties and antioxidant effects [87] and can be an energy source for rumen microbes [76]. These compounds have the potential to have environmental impacts through a reduction in urinary $\mathrm{N}$ excretion; however, $\mathrm{McC}$ arthy et al. [76] reported no significant effects on urinary $\mathrm{N}$ excretion from dairy cattle grazing multispecies swards, which is likely a result from minimal consumption of plantain within a sward (compared to grasses or legumes).

Table 2. Mineral concentrations of common forbs and grasses used in multispecies swards.

\begin{tabular}{ccccc}
\hline & \multicolumn{2}{c}{ Forbs } & \multicolumn{2}{c}{ Grasses } \\
\hline Element & Plantain $^{\mathbf{a}}$ & Chicory $^{\mathbf{a}}$ & Orchardgrass $^{\mathbf{b}}$ & Perennial Ryegrass $^{\mathbf{c}}$ \\
\hline $\mathrm{r}$ & $\mathrm{g} \mathrm{kg}^{-1}$ & \\
$\mathrm{P}$ & 3.9 & 4.7 & 3 & 2 \\
$\mathrm{~K}$ & 25 & 36 & 27 & 4 \\
$\mathrm{Ca}$ & 19 & 18 & 5 & 2 \\
$\mathrm{Mg}$ & 3.5 & 4.8 & 3 & - \\
$\mathrm{Mn}$ & 89 & 170 & 112 & 8 \\
$\mathrm{Cu}$ & 22 & 32 & 7 & 5 \\
$\mathrm{~B}$ & 25 & 33 & 21 & 39 \\
$\mathrm{Zn}$ & 31 & 45 & 76 & \\
\hline
\end{tabular}

a [57]; ${ }^{\mathrm{b}}[88] ;{ }^{\mathrm{c}}$ [89]; mineral elements most likely to require supplementation under grazing may include $\mathrm{Ca}, \mathrm{P}$, $\mathrm{Na}, \mathrm{Co}, \mathrm{Cu}, \mathrm{I}, \mathrm{Se}$, and $\mathrm{Zn}[90,91]$.

\subsection{Internal Parasite Load}

Production losses from gastrointestinal parasite load in livestock are widely reported $[92,93]$. Sub-clinical infection from internal parasites can reduce lamb growth rate by $40 \%$, which can affect the economic returns of an operation [94]. Control of gastrointestinal parasites has generally been achieved through the use of anthelmintic drugs; however, increased resistance of parasites to common anthelmintics has been reported in goats, sheep, and cattle [93]. In addition, common standards for organic food production prohibits the routine use of anthelmintics [95]. Alternative methods for gastrointestinal parasite controls are currently the subject of various investigations [94], and among these, the inclusion of forbs and other alternative forage species have been suggested [61,94]. Marley et al. [94] indicate that although fecal egg counts did not differ between lambs grazing chicory or ryegrass-white clover pastures, there were fewer total adult abomasal helminths when lambs grazed chicory monoculture pastures. Peña-Espinoza et al. [96] report a reduction in worm burden and fecal egg counts in Jersey bull calves, when chicory composed $70 \%$ of the diet. Furthermore, lambs grazing multispecies swards were shown to have reduced parasite loads, requiring fewer anthelmintic treatments than those grazing perennial ryegrass-white clover or perennial ryegrass monoculture pastures [61]. The 
exact mechanisms by which these forages affect ruminant parasite load remains poorly understood [94], but it might be hypothesized that plant secondary metabolites may play a role in having anthelmintic effects $[93,97]$. Reductions in intestinal parasite load will continue to be important factors in livestock production, since their reduction will have impacts in improving animal welfare, while also decreasing the reliance on purchased anthelmintics or other medicine.

\subsection{Weed Management}

Herbicides are an important tool for reducing weed encroachment in pasture systems, but their use in multispecies swards presents an inherent challenge due to the species diversity of these swards. Selective herbicides have been widely utilized for selective weed control in cropping systems or monoculture pastures [98]. An example comes from the auxin herbicide family, where several of these herbicides are effective against certain broadleaf weeds but can simultaneously affect clovers within a pasture [98]. There are currently no herbicides specifically labeled for use in multispecies pastures; it is, therefore, important for producers to address any weed encroachment issues prior to planting [99].There is evidence to suggest that increased forage plant diversity might suppress weed invasion in pasture ecosystems $[17,100]$. The specific mechanisms for weed suppression in multispecies swards are difficult to define, since increased forage diversity is often positively correlated with high productivity [17]. However, it is suggested that increased soil cover improves resource use efficiency and reduces space for weeds to encroach and establish themselves in the swards [18]. It has been suggested that forage forbs may occupy the niche of broadleaf weeds within a pasture ecosystem. As a whole, pasture-species composition affects weed encroachment; mixtures based on tall fescue showed reduced weed pressure compared with mixtures based on smooth bromegrass (Bromus inermis Leyss.) [17]. Weedy species were also shown to be reduced across several sites in Ireland [101] and at a single site in the United Kingdom [102] and in northeastern U.S.A. [71], comparing monoculture ryegrass pastures and multispecies swards of contrasting species composition. In general, maintaining productive pasture communities and the even distribution of pasture species across a pasture are effective methods to reduce weed encroachment [17]. It is important to note that pasture productivity and forage accumulation may not always have a similar connotation, especially in instances where weed encroachment may increase the pasture biomass, and the animals do not select these species while grazing, or instances where weeds may be toxic.

\section{Challenges Related with Multispecies Sward Management}

\subsection{Fodder Quality}

Conserved forage is an important resource for feeding ruminants during winter periods in temperate regions. Hay and silage are among the most widely utilized methods for forage conservation; however, unpredictable weather conditions and proper storage methods present challenges to ensuring a high nutritive value of the product [103]. Diverse pastures (e.g., multispecies swards) can also present important challenges in terms of drying, since forage species have different drying rates at a field scale [104]. Grass species generally dry faster than legumes, and differences exist within legume species where, for instance, clovers tend to dry slower than alfalfa [104]. Baling hay at high moisture concentration levels has the risk of potentially creating an environment for mold growth and reducing the overall nutritive value of the product [105].

For these reasons, making silage is a more attractive option for producers in much of the temperate regions of the world. There is a paucity of literature regarding silage quality from multispecies swards. So far, there is evidence to suggest that silage production from multispecies swards may provide additional challenges, especially given the fact that forbs tend to have low DM concentrations $[57,106,107]$. High moisture concentrations in chicory and plantain have been shown to impair the fermentation profile and reduce the overall nutritive value of silages made from these species in monoculture [106,107]. However, under 
favorable weather conditions, field-wilted multispecies mixtures preserved satisfactorily as silage, compared with a $\mathrm{N}$-fertilized perennial ryegrass monoculture silage $[62,73,103]$. Under adverse weather conditions (i.e., high moisture), multispecies mixtures have shown reduced ensilability capacities [62,73]. Therefore, although silage from multispecies swards can be of adequate nutritive value for livestock, there will be additional challenges related with the production of silage, especially due to required field wilting [62,103].

\subsection{Plant-Animal Interactions}

The dynamics between plants and herbivores is quite complex. While it is known that grazing ruminants can alter plant species diversity in improved grasslands [108], less is known regarding the impact of more complex (relative to grass monocultures) forage mixtures on animal performance (for review, see [18]). Selection of specific plant species, and plant parts within species, can result in greater heterogeneity in mixed species swards, with some patches being overgrazed and others undergrazed [109]. This can result in microhabitats, which provide an environment for a greater range of forage species to survive. On the other hand, continuous stocking can result in desirable forage species being weakened and lost over time by high grazing intensities, as animals repeatedly graze favorite patches. These open areas provide opportunities for undesirable species, such as weeds or lower-producing species to thrive, resulting in a reduced carrying capacity of the pastures [18].

When presented with mixed species swards, grazing ruminants show clear preferences for certain species [110]. For example, cattle and sheep offered varying proportions of perennial ryegrass and white clover in adjacent monocultures have consistently selected a diet containing greater than $70 \%$ white clover $[110,111]$. This shows active selection to maintain this ratio, even when the proportion of white clover was low relative to the perennial ryegrass.

Cattle, sheep, and goats all have different grazing behavior and diet selection patterns, which can affect sward structure. For example, swards grazed by cattle have greater proportions of white clover than the same swards grazed by sheep [112] due to sheep selecting a higher-quality diet than cattle. This is believed to be due to sheep having prehensile lips, which allow them to select individual tillers, while cattle use their tongues to sweep larger amounts of lower-quality forages into their mouths [113-115].

There is still much to be learned regarding grazing behavior in complex forage mixtures. There is evidence that increased plant species richness particularly benefits low-input grazing systems through the improvement of primary (plant) production, reduced weed invasion, and improved system resilience to climatic extremes such as drought [71,72]. However, little is yet known about the impacts of secondary (animal) production and wider benefits such as ecosystem services. A better understanding of the interactions between grazed plants and grazing animals is needed to create and maintain both desired pasture diversity and optimum animal performance under various soils, climates, and grazing management.

One major limitation to currently available research is that it was often conducted either with monocultures or with simple two-species swards, which can not necessarily be extrapolated to more complex forage mixtures that contain multiple plant functional groups. While this additional research is needed, conducting such research is expensive and challenging, as there are many potentially confounding variables that may limit the repeatability of results and best management practices across a wide array of situations.

\subsection{Forage Forb Persistence}

Long-term persistence of multispecies swards has been a challenge among those who have implemented these production systems. Most specifically, the forb component of the sward often fails to persist beyond three years $[11,23,66,67]$. The grass-legume components of multispecies swards tend to persist well beyond forbs, which is beneficial for the overall system [11]. Forbs can be adequately re-established into grazed pastures through frost 
seeding (during winter months), no-till seeding, or broadcast seeding [67]. Despite the sowing method of choice, it is suggested that existing vegetation should be suppressed through either increasing grazing intensity or mowing the pastures, in order to improve forb seedling emergence [67]. Altogether, it might be suggested that further evaluation into the grazing tolerance of forb species is still required. Future research efforts should be allocated towards developing and improving the grazing tolerance of these forage forbs.

\section{Other Considerations}

Recent shifts to focus on enhancing the environmental sustainability of ruminant production systems through reduced inputs have resulted in increased interest in sowing multispecies pasture systems. There are challenges associated with multispecies swards, and these warrant further study, e.g., persistence of the forb component needs to be further addressed, since poor persistence might deter producer adoption of these systems. However, losses of the forb component may still result in a grass-legume sward, which is still beneficial as the fundamental component of a low-input system. Further breeding and selection efforts, as well as developing improved grazing management practices, are still required in order to improve persistence of these species. Multispecies swards have the potential to significantly reduce pasture nutrient input requirements. However, improvements in the forb component will likely increase farmer adoption of these swards, thus fully realizing their agri-environmental potential. Furthermore, the environmental impacts of implementing multispecies pasture systems warrant further research and review, especially in relation to differences in nutrient inputs.

Author Contributions: Conceptualization, H.S. and K.S.; Investigation, D.M.J., H.S., K.S., J.C.B.D.J.; Data collection, D.M.J., H.S., K.S., J.C.B.D.J.; Writing-original draft preparation, D.M.J., H.S., K.S., J.C.B.D.J.; Writing-review and editing, D.M.J., H.S., K.S., J.C.B.D.J.; Supervision, H.S., K.S., J.C.B.D.J. All authors have read and agreed to the published version of the manuscript.

Funding: This research received no external funding.

Institutional Review Board Statement: Ethical review and approval were not needed as it is a literature review which do not involve additional animal experimentation.

Informed Consent Statement: Not applicable.

Data Availability Statement: Not applicable.

Conflicts of Interest: The authors declare no conflict of interest.

Disclaimer: Mention of trade names or commercial products in this article is solely for the purpose of providing specific information and does not imply either recommendation or endorsement by the U.S. Department of Agriculture. The USDA is an equal opportunity provider and employer.

\section{References}

1. Dillon, P.; Crosse, S.; O'Brien, B.; Mayes, R.W. The effect of forage type and level of concentrate supplementation on the performance of spring-calving dairy cows in early lactation. Grass Forage Sci. 2002, 57, 212-223. [CrossRef]

2. Lambin, E.F.; Meyfroidt, P. Global land use change, economic globalization, and the looming land scarcity. Proc. Natl. Acad. Sci. USA 2011, 108, 3465. [CrossRef] [PubMed]

3. Hewins, D.B.; Lyseng, M.P.; Schoderbek, D.F.; Alexander, M.; Willms, W.D.; Carlyle, C.; Chang, S.X.; Bork, E.W. Grazing and climate effects on soil organic carbon concentration and particle-size association in northern grasslands. Sci. Rep. 2018, 8, 1-9. [CrossRef]

4. Raney, T. The State of Food and Agriculture: Livestock in the Balance; Food and Agriculture Organization of the United Nations: Rome, Italy, 2009.

5. Herrero, M.; Henderson, B.; Havlík, P.; Thornton, P.K.; Conant, R.T.; Smith, P.; Wirsenius, S.; Hristov, A.N.; Gerber, P.; Gill, M.; et al. Greenhouse gas mitigation potentials in the livestock sector. Nat. Clim. Chang. 2016, 6, 452-461. [CrossRef]

6. Peters, M.; Herrero, M.; Fisher, M.; Erb, K.-H.; Rao, I.; Subbarao, G.V.; Castro, A.; Arango, J.; Chará, J.; Murgueitio, E.; et al. Challenges and opportunities for improving eco-efficiency of tropical forage-based systems to mitigate greenhouse gas emissions. Trop. Grassl. Forrajes Trop. 2013, 1, 156-167. [CrossRef] 
7. Boddey, R.; Macedo, R.; Tarré, R.; Ferreira, E.; de Oliveira, O.; Rezende, C.D.P.; Cantarutti, R.; Pereira, J.; Alves, B.; Urquiaga, S. Nitrogen cycling in Brachiaria pastures: The key to understanding the process of pasture decline. Agric. Ecosyst. Environ. 2004 103, 389-403. [CrossRef]

8. Woodard, K.R.; French, E.C.; Sweat, L.A.; Graetz, D.A.; Sollenberger, L.E.; Macoon, B.; Portier, K.M.; Rymph, S.J.; Wade, B.L.; Prine, G.M.; et al. Nitrogen Removal and Nitrate Leaching for Two Perennial, Sod-Based Forage Systems Receiving Dairy Effluent. J. Environ. Qual. 2003, 32, 996-1007. [CrossRef]

9. Kirschenmann, F.L. Potential for a New Generation of Biodiversity in Agroecosystems of the Future. Agron. J. 2007, 99, 373-376. [CrossRef]

10. Tallowin, J.R.B.; Rook, A.J.; Rutter, M. Impact of grazing management on biodiversity of grasslands. Anim. Sci. 2005, 81, 193-198. [CrossRef]

11. Grace, C.; Boland, T.M.; Sheridan, H.; Lott, S.; Brennan, E.; Fritch, R.; Lynch, M.B. The effect of increasing pasture species on herbage production, chemical composition and utilization under intensive sheep grazing. Grass Forage Sci. 2016, 73, 852-864. [CrossRef]

12. Sollenberger, L.E.; Kohmann, M.M.; Dubeux, J.; Silveira, M.L. Grassland Management Affects Delivery of Regulating and Supporting Ecosystem Services. Crop. Sci. 2019, 59, 441-459. [CrossRef]

13. Cummins, S.; Finn, J.A.; Richards, K.G.; Lanigan, G.J.; Grange, G.; Brophy, C.; Cardenas, L.M.; Misselbrook, T.H.; Reynolds, C.K.; Krol, D.J. Beneficial effects of multi-species mixtures on N2O emissions from intensively managed grassland swards. Sci. Total. Environ. 2021, 792, 148163. [CrossRef] [PubMed]

14. Allen, V.; Batello, C.; Berretta, E.; Hodgson, J.; Kothmann, M.; Li, X.; McIvor, J.G.; Milne, J.; Morris, C.D.; Peeters, A.; et al. An international terminology for grazing lands and grazing animals. Grass Forage Sci. 2011, 66, 2-28. [CrossRef]

15. Goh, K.; Bruce, G. Comparison of biomass production and biological nitrogen fixation of multi-species pastures (mixed herb leys) with perennial ryegrass-white clover pasture with and without irrigation in Canterbury, New Zealand. Agric. Ecosyst. Environ. 2005, 110, 230-240. [CrossRef]

16. Delaby, L.; Finn, J.A.; Grange, G.; Horan, B. Pasture-Based Dairy Systems in Temperate Lowlands: Challenges and Opportunities for the Future. Front. Sustain. Food Syst. 2020, 4. [CrossRef]

17. Tracy, B.F.; Sanderson, M.A. Forage productivity, species evenness and weed invasion in pasture communities. Agric. Ecosyst. Environ. 2004, 102, 175-183. [CrossRef]

18. Soder, K.J.; Rook, A.J.; Sanderson, M.A.; Goslee, S.C. Interaction of Plant Species Diversity on Grazing Behavior and Performance of Livestock Grazing Temperate Region Pastures. Crop. Sci. 2007, 47, 416-425. [CrossRef]

19. Wilkins, P.W.; Humphreys, M.O. Progress in breeding perennial forage grasses for temperate agriculture. J. Agric. Sci. 2003, 140, 129-150. [CrossRef]

20. McDonagh, J.; O’Donovan, M.; McEvoy, M.; Gilliland, T.J. Genetic gain in perennial ryegrass (Lolium perenne) varieties 1973 to 2013. Euphytica 2016, 212, 187-199. [CrossRef]

21. Lee, J.M.; Sathish, P.; Donaghy, D.J.; Roche, J.R. Plants Modify Biological Processes to Ensure Survival following Carbon Depletion: A Lolium perenne Model. PLoS ONE 2010, 5, e12306. [CrossRef]

22. Harris, S.L.; Thom, E.R.; Clark, D.A. Effect of high rates of nitrogen fertiliser on perennial ryegrass growth and morphology in grazed dairy pasture in northern New Zealand. N. Z. J. Agric. Res. 1996, 39, 159-169. [CrossRef]

23. Grace, C.; Boland, T.M.; Sheridan, H.; Brennan, E.; Fritch, R.; Lynch, M.B. The effect of grazing versus cutting on dry matter production of multispecies and perennial ryegrass-only swards. Grass Forage Sci. 2019. [CrossRef]

24. Mote, R.S.; Hill, N.S.; Uppal, K.; Tran, V.T.; Jones, D.P.; Filipov, N.M. Metabolomics of fescue toxicosis in grazing beef steers. Food Chem. Toxicol. 2017, 105, 285-299. [CrossRef] [PubMed]

25. Hancock, D.W.; Andrae, J. Novel Endophyte-Infected Tall Fescue. 2009. Available online: https://hdl.handle.net/10724/12210 (accessed on 5 May 2021).

26. Van Santen, E.; Sleper, D.A. Orchardgrass. In Cool-Season Forage Grasses; Wiley Online Library: Hoboken, NJ, USA, 1996; pp. 503-534.

27. Sanada, Y.; Gras, M.-C.; van Santen, E. Cocksfoot. In Fodder Crops and Amenity Grasses; Boller, B., Posselt, U.K., Veronesi, F., Eds.; Springer: New York, NY, USA, 2010; pp. 317-328.

28. Casler, M.; Undersander, D.; Papadopolous, Y.; Bittman, S.; Hunt, D.; Mathison, R.; Min, D.; Robins, J.; Cherney, J.; Acharya, S.; et al. Sparse-Flowering Orchardgrass Represents an Improvement in Forage Quality During Reproductive Growth. Crop. Sci. 2014, 54, 421-429. [CrossRef]

29. Casler, M.D.; Brink, G.E.; Cherney, J.H. Registration of 'Azov' Meadow Fescue. J. Plant Regist. 2017, 11, 9-14. [CrossRef]

30. Casler, M.D.; Brink, G.E.; Cherney, J.H.; van Santen, E.; Humphreys, M.W.; Yamada, T.; Tamura, K.I.; Ellison, N.W.; Opitz, C. Registration of 'Hidden Valley' Meadow Fescue. J. Plant Regist. 2015, 9, 294-298. [CrossRef]

31. Undersander, D.J.; Albert, B.; Cosgrove, D.; Johnson, D.; Peterson, P. Pastures for Profit: A Guide to Rotational Grazing; Cooperative Extensiton Publications, University of Wisconsin-Extension: Madison, WI, USA, 2002.

32. Peyraud, J.L.; Le Gall, A.; Lüscher, A. Potential food production from forage legume-based-systems in Europe: An overview. Ir. J. Agric. Food Res. 2009, 48, 115-135.

33. Blaser, R.E.; Skrdla, W.H.; Taylor, T.H. Ecological and Physiological Factors in Compounding Forage Seed Mixtures. In Advances in Agronomy; Norman, A.G., Ed.; Academic Press: Cambridge, MA, USA, 1952; pp. 179-219. 
34. Rochon, J.J.; Doyle, C.J.; Greef, J.M.; Hopkins, A.; Molle, G.; Sitzia, M.; Scholefield, D.; Smith, C.J. Grazing legumes in Europe: A review of their status, management, benefits, research needs and future prospects. Grass Forage Sci. 2004, 59, 197-214. [CrossRef]

35. Muir, J.P.; Pitman, W.D.; Foster, J.L. Sustainable, low-input, warm-season, grass-legume grassland mixtures: Mission (nearly) impossible? Grass Forage Sci. 2011, 66, 301-315. [CrossRef]

36. Moot, D.J. An overview of dryland legume research in New Zealand. Crop. Pasture Sci. 2012, 63, 726-733. [CrossRef]

37. Jahufer, M.Z.Z.; Ford, J.L.; Widdup, K.H.; Harris, C.; Cousins, G.; Ayres, J.F.; Lane, L.A.; Hofmann, R.; Ballizany, W.L.; Mercer, C.F.; et al. Improving white clover for Australasia. Crop. Pasture Sci. 2012, 63, 739-745. [CrossRef]

38. Bouton, J. The economic benefits of forage improvement in the United States. Euphytica 2006, 154, 263-270. [CrossRef]

39. Sanderson, M.A.; Skinner, R.H.; Barker, D.J.; Edwards, G.; Tracy, B.F.; Wedin, D.A. Plant Species Diversity and Management of Temperate Forage and Grazing Land Ecosystems. Crop. Sci. 2004, 44, 1132-1144. [CrossRef]

40. Nyfeler, D.; Huguenin-Elie, O.; Suter, M.; Frossard, E.; Lüscher, A. Grass-legume mixtures can yield more nitrogen than legume pure stands due to mutual stimulation of nitrogen uptake from symbiotic and non-symbiotic sources. Agric. Ecosyst. Environ. 2011, 140, 155-163. [CrossRef]

41. Cardinale, B.J.; Wright, J.P.; Cadotte, M.W.; Carroll, I.T.; Hector, A.; Srivastava, D.S.; Loreau, M.; Weis, J.J. Impacts of plant diversity on biomass production increase through time because of species complementarity. Proc. Natl. Acad. Sci. USA 2007, 104, 18123-18128. [CrossRef]

42. Sleugh, B.; Moore, K.J.; George, J.R.; Brummer, E.C. Binary Legume-Grass Mixtures Improve Forage Yield, Quality, and Seasonal Distribution. Agron. J. 2000, 92, 24-29. [CrossRef]

43. Lüscher, A.; Mueller-Harvey, I.; Soussana, J.F.; Rees, R.M.; Peyraud, J.L. Potential of legume-based grassland-livestock systems in Europe: A review. Grass Forage Sci. 2014, 69, 206-228. [CrossRef]

44. Schultze-Kraft, R.; Rao, I.M.; Peters, M.; Clements, R.J.; Bai, C.; Liu, G. Tropical forage legumes for environmental benefits: An overview. Trop. Grassl.-Forrajes Trop. 2018, 6, 1-14. [CrossRef]

45. Jensen, E.S.; Peoples, M.B.; Boddey, R.; Gresshoff, P.M.; Hauggaard-Nielsen, H.; Alves, B.J.; Morrison, M.J. Legumes for mitigation of climate change and the provision of feedstock for biofuels and biorefineries. A review. Agron. Sustain. Dev. 2011, 32, 329-364. [CrossRef]

46. Brouwer, F.; Hellegers, P. The nitrate directive and farming practice in the European Union. In European Environment; Wiley Online Library: Hoboken, NJ, USA, 1996; Volume 6, pp. 204-209.

47. European Commission. The European Green Deal. 2019. Available online: https://ec.europa.eu/info/strategy/priorities-2019-2 024/european-green-deal_en (accessed on 10 June 2021).

48. European Commission. Farm to Fork Strategy: For a Fair, Healthy and Environmentally-Friendly Food System. 2020. Available online: https:/ / ec.europa.eu/food/horizontal-topics/farm-fork-strategy_en (accessed on 10 June 2021).

49. House, T.W. FACT SHEET: President Biden Sets 2030 Greenhouse Gas Pollution Reduction Target Aimed at Creating Good-Paying Union Jobs and Securing U.S. Leadership on Clean Energy Technologies. 2021. Available online: https://bo.usembassy.gov/factsheet-president-biden-sets-2030-greenhouse-gas-pollution-reduction-target/ (accessed on 10 June 2021).

50. Scarsbrook, M.R.; Melland, A. Dairying and water-quality issues in Australia and New Zealand. Anim. Prod. Sci. 2015, 55, 856-868. [CrossRef]

51. Government, N.Z. National Policy Statement for Freshwater Management; New Zealand Government: Wellington, New Zealand, 2014.

52. United Nations Climate Change. The Paris Agreement. 2015. Available online: https://unfccc.int/process-and-meetings/theparis-agreement/the-paris-agreement (accessed on 10 June 2021).

53. Glanemann, N.; Willner, S.N.; Levermann, A. Paris Climate Agreement passes the cost-benefit test. Nat. Commun. 2020, 11, 1-11. [CrossRef]

54. Finn, J.A.; Kirwan, L.; Connolly, J.; Sebastià, M.T.; Helgadottir, A.; Baadshaug, O.H.; Bélanger, G.; Black, A.; Brophy, C.; Collins, R.P.; et al. Ecosystem function enhanced by combining four functional types of plant species in intensively managed grassland mixtures: A 3-year continental-scale field experiment. J. Appl. Ecol. 2013, 50, 365-375. [CrossRef]

55. Tozer, K.; Barker, G.; Cameron, C.; Wilson, D.; Loick, N. Effects of including forage herbs in grass-legume mixtures on persistence of intensively managed pastures sampled across three age categories and five regions. N. Z. J. Agric. Res. 2016, 59, 250-268. [CrossRef]

56. Foster, L. Herbs in Pastures. Development Research in Britain, 1850-1984. Biol. Agric. Hortic. 1988, 5, 97-133. [CrossRef]

57. Sanderson, M.A.; Labreveux, M.; Hall, M.H.; Elwinger, G.F. Nutritive Value of Chicory and English Plantain Forage. Crop. Sci. 2003, 43, 1797-1804. [CrossRef]

58. Cichota, R.; McAuliffe, R.; Lee, J.; Minnee, E.; Martin, K.; Brown, H.E.; Moot, D.J.; Snow, V. Forage chicory model: Development and evaluation. Field Crop. Res. 2019, 246, 107633. [CrossRef]

59. Rumball, W. Grasslands Puna' chicory (Cichorium intybus L.). N. Z. J. Exp. Agric. 1986, 14, 105-107.

60. Rumball, W.; Keogh, R.G.; Lane, G.E.; Miller, J.E.; Claydon, R.B. ‘Grasslands Lancelot' plantain (Plantago lanceolata L.). N. Z. J. Agric. Res. 1997, 40, 373-377. [CrossRef]

61. Grace, C.; Lynch, M.B.; Sheridan, H.; Lott, S.; Fritch, R.; Boland, T.M. Grazing multispecies swards improves ewe and lamb performance. Animal 2019, 13, 1721-1729. [CrossRef]

62. Moloney, T.; Sheridan, H.; Grant, J.; O'Riordan, E.; O'Kiely, P. Conservation efficiency and nutritive value of silages made from grass-red clover and multi-species swards compared with grass monocultures. Ir. J. Agric. Food Res. 2021, 59. [CrossRef] 
63. Roca-Fernández, A.I.; Peyraud, J.L.; Delaby, L.; Delagarde, R. Pasture intake and milk production of dairy cows rotationally grazing on multi-species swards. Animal 2016, 10, 1448-1456. [CrossRef]

64. Bryant, R.H.; Miller, M.E.; Greenwood, S.L.; Edwards, G. Milk yield and nitrogen excretion of dairy cows grazing binary and multispecies pastures. Grass Forage Sci. 2017, 72, 806-817. [CrossRef]

65. Gregorini, P.; Minnee, E.; Griffiths, W.; Lee, J. Dairy cows increase ingestive mastication and reduce ruminative chewing when grazing chicory and plantain. J. Dairy Sci. 2013, 96, 7798-7805. [CrossRef] [PubMed]

66. Soder, K.; Sanderson, M.; Stack, J.; Muller, L. Intake and Performance of Lactating Cows Grazing Diverse Forage Mixtures. J. Dairy Sci. 2006, 89, 2158-2167. [CrossRef]

67. Skinner, R.H.; Dell, C.J. Reestablishing Chicory into Multi-Species Perennial Pastures. Forage Grazinglands 2010, 8, 1-6. [CrossRef]

68. Skinner, R.H.; Dell, C.J. Yield and Soil Carbon Sequestration in Grazed Pastures Sown with Two or Five Forage Species. Crop. Sci. 2016, 56, 2035-2044. [CrossRef]

69. Sanderson, M. Nutritive Value and Herbage Accumulation Rates of Pastures Sown to Grass, Legume, and Chicory Mixtures. Agron. J. 2010, 102, 728-733. [CrossRef]

70. Nobilly, F.; Bryant, R.; McKenzie, B.; Edwards, G. Productivity of rotationally grazed simple and diverse pasture mixtures under irrigation in Canterbury. Proc. N. Z. Grassl. Assoc. 2013, 165-172. [CrossRef]

71. Sanderson, M.A.; Soder, K.J.; Muller, L.D.; Klement, K.D.; Skinner, R.H.; Goslee, S.C. Forage Mixture Productivity and Botanical Composition in Pastures Grazed by Dairy Cattle. Agron. J. 2005, 97, 1465-1471. [CrossRef]

72. Skinner, R.H.; Gustine, D.L.; Sanderson, M.A. Growth, Water Relations, and Nutritive Value of Pasture Species Mixtures under Moisture Stress. Crop. Sci. 2004, 44, 1361-1369. [CrossRef]

73. Moloney, T. Multi-species swards for silage production. Ph.D. Dissertation, University College Dublin, Dublin, Ireland, 2018.

74. Hooper, D.U.; Chapin Iii, F.S.; Ewel, J.J.; Hector, A.; Inchausti, P.; Lavorel, S.; Lawton, J.H.; Lodge, D.M.; Loreau, M.; Naeem, S.; et al. Effect of biodiversity on ecosystem functioning: A consensys of current knowledge. Ecol. Monogr. 2005, 75, 3-35. [CrossRef]

75. Barry, T.N. The feeding value of chicory (Cichorium intybus) for ruminant livestock. J. Agric. Sci. 1998, 131, 251-257. [CrossRef]

76. McCarthy, K.; McAloon, C.; Lynch, M.; Pierce, K.; Mulligan, F. Herb species inclusion in grazing swards for dairy cows-A systematic review and meta-analysis. J. Dairy Sci. 2020, 103, 1416-1430. [CrossRef]

77. Gregorini, P.; Gunter, S.A.; Masino, C.A.; Beck, P. Effects of ruminal fill on short-term herbage intake rate and grazing dynamics of beef heifers. Grass Forage Sci. 2007, 62, 346-354. [CrossRef]

78. Barry, T.; Hoskin, S.; Wilson, P. Novel forages for growth and health in farmed deer. N. Z. Vet. J. 2002, 50, 244-251. [CrossRef] [PubMed]

79. Kusmartono; Shimada, A.; Stafford, K.J.; Barry, T.N. Intra-ruminal particle size reduction in deer fed fresh perennial ryegrass (Lolium perenne) or chicory (Cichorium intybus). J. Agric. Sci. 1996, 127, 525-531. [CrossRef]

80. Foster, J.G.; Fedders, J.M.; Clapham, W.M.; Robertson, J.W.; Bligh, D.P.; Turner, K.E. Nutritive Value and Animal Selection of Forage Chicory Cultivars Grown in Central Appalachia. Agron. J. 2002, 94, 1034-1042. [CrossRef]

81. Foster, J.G.; Cassida, K.A.; Sanderson, M.A. Seasonal variation in sesquiterpene lactone concentration and composition of forage chicory (Cichorium intybus L.) cultivars. Grass Forage Sci. 2011, 66, 424-433. [CrossRef]

82. Box, L.A.; Edwards, G.R.; Bryant, R.H. Seasonal and diurnal changes in aucubin, catalpol and acteoside concentration of plantain herbage grown at high and low $\mathrm{N}$ fertiliser inputs. N. Z. J. Agric. Res. 2018, 62, 343-353. [CrossRef]

83. Gardiner, C.; Clough, T.; Cameron, K.; Di, H.; Edwards, G.; De Klein, C. Potential for forage diet manipulation in New Zealand pasture ecosystems to mitigate ruminant urine derived N2O emissions: A review. N. Z. J. Agric. Res. 2016, 59, 301-317. [CrossRef]

84. Tamura, Y. Effects of Temperature, Shade, and Nitrogen Application on the Growth and Accumulation of Bioactive Compounds in Cultivars of Plantago lanceolata L. Jpn. J. Crop. Sci. 2001, 70, 548-553. [CrossRef]

85. Pae, H.O.; Oh, G.S.; Choi, B.M.; Shin, S.; Chai, K.Y.; Oh, H.; Kim, J.M.; Kim, H.J.; Jang, S.I.; Chung, H.T. Inhibitory effects of the stem bark of Catalpa ovata G. Don. (Bignoniaceae) on the productions of tumor necrosis factor-alpha and nitric oxide by the lipopolisaccharide-stimulated RAW 264.7 macrophages. J. Ethnopharmacol. 2003, 88, 287-291. [CrossRef]

86. Navarrete, S.; Kemp, P.D.; Pain, S.J.; Back, P.J. Bioactive compounds, aucubin and acteoside, in plantain (Plantago lanceolata L.) and their effect on in vitro rumen fermentation. Anim. Feed. Sci. Technol. 2016, 222, 158-167. [CrossRef]

87. Chen, C.H.; Lin, Y.S.; Chien, M.Y.; Hou, W.C.; Hu, M.L. Antioxidant and antihypertensive activities of acteoside and its analogs. Bot. Stud. 2012, 53, 421-429.

88. Jung, G.A.; Shaffer, J.A.; Everhart, J.R.; Varga, G.A. Performance of 'Grasslands Puna' Chicory at Different Management Levels Agron. J. 1996, 88, 104-111. [CrossRef]

89. Reed, K.F.M.; Walsh, J.R.; Cross, P.A.; McFarlane, N.M.; Sprague, M.A. Ryegrass endophyte (Neotyphodium lolii) alkaloids and mineral concentrations in perennial ryegrass (Lolium perenne) from southwest Victorian pasture. Aust. J. Exp. Agric. 2004, 44, 1185-1194. [CrossRef]

90. Corah, L. Trace mineral requirements of grazing cattle. Anim. Feed. Sci. Technol. 1996, 59, 61-70. [CrossRef]

91. McDowell, L.R. Feeding minerals to cattle on pasture. Anim. Feed. Sci. Technol. 1996, 60, 247-271. [CrossRef]

92. Sykes, A.R. Parasitism and production in farm animals. Anim. Sci. 1994, 59, 155-172. [CrossRef]

93. Min, B.R.; Hart, S.P. Tannins for suppression of internal parasites. J. Anim. Sci. 2003, 81, E102-E109. 
94. Marley, C.; Cook, R.; Keatinge, R.; Barrett, J.; Lampkin, N. The effect of birdsfoot trefoil (Lotus corniculatus) and chicory (Cichorium intybus) on parasite intensities and performance of lambs naturally infected with helminth parasites. Vet. Parasitol. 2002, 112, 147-155. [CrossRef]

95. Lu, C.; Gangyi, X.; Kawas, J. Organic goat production, processing and marketing: Opportunities, challenges and outlook. Small Rumin. Res. 2010, 89, 102-109. [CrossRef]

96. Peña-Espinoza, M.; Thamsborg, S.M.; Desrues, O.; Hansen, T.V.A.; Enemark, H.L. Anthelmintic effects of forage chicory (Cichorium intybus) against gastrointestinal nematode parasites in experimentally infected cattle. Parasitology 2016, 143, 1279-1293. [CrossRef]

97. Alomar, D.; Ruiz, P.; Balocchi, O.; Valenzuela, G.; Goic, D. Finishing lambs on a chicory-plantain mixture or a temperate grass-based pasture: Live weight gain and gastrointestinal parasitism. Cienc. E Investing. Agrar. 2018, 45, 11-20. [CrossRef]

98. Ghanizadeh, H.; Harrington, K.C. Weed Management in New Zealand Pastures. Agronomy 2019, 9, 448. [CrossRef]

99. Glassey, C.B.; Clark, C.E.F.; Roach, C.G.; Lee, J.M. Herbicide application and direct drilling improves establishment and yield of chicory and plantain. Grass Forage Sci. 2012, 68, 178-185. [CrossRef]

100. Tilman, D.; Wedin, D.; Knops, J. Productivity and sustainability influenced by biodiversity in grassland ecosystems. Nature 1996, 379, 718-720. [CrossRef]

101. Connolly, J.; Finn, J.A.; Black, A.D.; Kirwan, L.; Brophy, C.; Lüscher, A. Effects of multi-species swards on dry matter production and the incidence of unsown species at three Irish sites. Ir. J. Agric. Food Res. 2009, 48, 243-260.

102. Beaumont, D.A.; Storkey, J.; Eales, G.; Jones, H.E.; LeCocq, K.; Saunders, K.S.; Stagg, B.; Lee, M.R.F. Impact of tillage methods and sowing rates on yield and weed suppression in multi-species swards. In Proceedings of the Meeting the Future Demands for Grassland Production, Helsinki, Finland, 19 October 2020; pp. 445-447.

103. Moloney, T.; Sheridan, H.; Grant, J.; O’Riordan, E.; O'Kiely, P. Yield of binary- and multi-species swards relative to single-species swards in intensive silage systems. Ir. J. Agric. Food Res. 2021, 59. [CrossRef]

104. Rotz, C.A. Field Curing of Forages. In Post-Harvest Physiology and Preservation of Forages; Crop Science Society of America: Madison, WI, USA, 1995; pp. 39-66.

105. Martinson, K.; Coblentz, W.; Sheaffer, C. The Effect of Harvest Moisture and Bale Wrapping on Forage Quality, Temperature, and Mold in Orchardgrass Hay. J. Equine Vet. Sci. 2011, 31, 711-716. [CrossRef]

106. Bariroh, N.R.; Bryant, R.H.; Black, A.D. Plantain silage quality under variable management practices. J. N. Z. Grassl. 2018, 119-124. [CrossRef]

107. Kälber, T.; Kreuzer, M.; Leiber, F. Silages containing buckwheat and chicory: Quality, digestibility and nitrogen utilisation by lactating cows. Arch. Anim. Nutr. 2012, 66, 50-65. [CrossRef]

108. Rook, A.J.; Tallowin, J.R. Grazing and pasture management for biodiversity benefit. Anim. Res. 2003, 52, 181-189. [CrossRef]

109. Bullock, J.M.; Marriott, C.A.; BBSRC Institute of Grassland and Environmental Research. Plant responses to grazing, and opportunities for manipulation. In Proceedings of the British Grassland Society Conference Held at the Cairn Hotel, Harrogate, England, 29 February-2 March 2000; pp. 17-26.

110. Rutter, S.M.; Orr, R.J.; Yarrow, N.H.; Champion, R.A. Dietary Preference of Dairy Cows Grazing Ryegrass and White Clover. J. Dairy Sci. 2004, 87, 1317-1324. [CrossRef]

111. Parsons, A.; Newman, J.; Penning, P.; Harvey, A.; Orr, R. Diet Preference of Sheep: Effects of Recent Diet, Physiological State and Species Abundance. J. Anim. Ecol. 1994, 63, 465. [CrossRef]

112. De La Hoz, V.M.B.; Wilman, D. Effects of cattle grazing, sheep grazing, cutting and sward height on a grass-white clover sward. J. Agric. Sci. 1981, 97, 699-706. [CrossRef]

113. Nicol, A.; Soper, M.; Stewart, A. Diversity of diet composition decreases with conjoint grazing of cattle with sheep and goats. In XX International Grassland Congress; University College Dublin: Dublin, Ireland, 2005.

114. Wright, I.; Connolly, J. Improved utilization of heterogeneous pastures by mixed species. In Recent Developments in the Nutrition of Herbivores; Institute National de la Recherche Agronomique: Paris, France, 1995.

115. Collins, H.; Nicol, A. The consequence for feed dry matter intake of grazing sheep, cattle and goats to the same residual herbage mass. In Proceedings of the New Zealand Society of Animal Production; New Zealand Society of Animal Production: Palmerston, New Zealand, 1986. 